\title{
Seedling size and woody competition most important predictors of growth following free-to-grow assessments in four boreal forest plantations
}

\author{
by Mahadev Sharma ${ }^{1,2}$, F. Wayne Bell ${ }^{1}$, R. G. White ${ }^{3}$, Andreé Morneault ${ }^{4}$ and William D. Towill ${ }^{5}$
}

\begin{abstract}
Improvements to forest management decisions require accurate and quantifiable information. We examined the effects of various classes of competitors on crop tree growth in the context of free-to-grow standards using regression analysis. We found that seedling size accounted for most of the variation in height and volume growth of jack pine (Pinus banksiana Lamb.) and black spruce (Picea mariana [Mill.] BSP) plantations. Including herbaceous and woody competition as explanatory variables explained the additional variation on crop tree growth significantly. In the plantation initiation phase (years 2 to 6), the presence of herbaceous competitors generally reduced conifer growth but in the first part of the stem-exclusion phase (years 7 to 12 ) increased their growth. In all four boreal plantations in this study, woody competitors reduced conifer growth in both the initiation and stem-exclusion phases. These results have relevance to forest managers who develop and/or use free-to-grow surveys.
\end{abstract}

Key words: vegetation management, silviculture, effectiveness monitoring, forest management, regeneration success, competition effect

\begin{abstract}
RÉSUMÉ
Lamélioration des décisions en matière d’aménagement forestier nécessite des informations précises et quantifiables. Nous avons examiné les effets de différentes classes de compétiteurs sur la croissance des arbres destinés à la récolte dans le contexte de normes équivalentes à la croissance sans entrave utilisée dans les analyses de régression. Nous avons constaté que la taille des semis expliquait en grande partie la variation de la croissance en hauteur et en volume des plantations de pin gris (Pinus banksiana Lamb.) et dépinette noire (Picea mariana [Mill.] BSP). L'inclusion de la concurrence végétale et arbustive sous forme de variables explicatives complétait de façon significative les raisons de la variation supplémentaire de la croissance des arbres formant la récolte. Au cours de la phase détablissement de la plantation (de la $2^{\mathrm{e}}$ à la $6^{\mathrm{e}}$ année), la présence de compétiteurs herbacés a généralement réduit la croissance des conifères, mais au cours de la première partie de la phase du développement de la tige (de la $7^{\mathrm{e}}$ à la $12^{\mathrm{e}}$ année), elle a permis d’accroître la croissance. Pour les quatre plantations nordiques de cette étude, les compétiteurs arbustifs ont entravé la croissance des conifères tant lors de la phase détablissement que lors du développement de la tige. Ces résultats ont de limportance pour les aménagistes forestiers qui élaborent ou encore qui utilisent les inventaires de croissance sans entrave.
\end{abstract}

Mots clés : contrôle de la végétation, sylviculture, suivi des paramètres, aménagement forestier, succès de la régénération, effet de la concurrence

\section{Introduction}

Improvements to forest management decisions depend on the availability of timely, accurate, and quantifiable information. An example of the information required by forest managers to predict stand growth and development is quantitative information about the regenerating forest. This information is often acquired through silvicultural effectiveness monitoring (SEM) programs. When conducted at various spatial and temporal scales, these programs provide opportunities for continuous improvement of management activities, such as setting prescriptions, implementing silvicultural treatments, developing best practices for management guides, and allocating investments. A key component of an SEM program is an efficient, transparent, and robust assessment procedure for determining what is referred to as free-to-grow (FTG) (White et al. 2005), i.e., the point at which crop trees are considered free of competition.

The FTG concept is accepted across most of North America (e.g., Cain 1999, Rose and Coate 2000, Jobidon et al. 2003, Jacobs et al. 2004, Jain et al. 2004, Gwaze et al. 2007, Lieffers et al. 2007). In clearcut and shelterwood silvicultural systems in Ontario, it is used as one of the critical points in determining regeneration success for conifers and hardwoods (OMNR 2001). Once designated as FTG, the regenerating forest stand can be re-entered into the forest inventory and used in subsequent allowable harvest calculations. As well, FTG is used by forest managers as an indicator of how well forests are growing, how well silvicultural prescriptions are working, and

\footnotetext{
${ }^{1}$ Ontario Forest Research Institute, Ministry of Natural Resources, 1235 Queen Street E., Sault Ste Marie, Ontario P6A 2E5

${ }^{2}$ Corresponding author. E-mail: mahadev.sharma@ontario.ca

${ }^{3}$ Ontario Ministry of Natural Resources, Northwest Science and Information Section, 808 Robertson St., Kenora, Ontario P9N 3X9

${ }^{4}$ Ontario Ministry of Natural Resources, Southcentral Science Section, 3301 Trout Lake Rd., North Bay, Ontario P1A 4L7

${ }^{5}$ Ontario Ministry of Natural Resources, Northwest Science and Information Section, 25th Side Road, Thunder Bay, Ontario P7C 4T9
} 
whether the desired future forest conditions are likely to be achieved (OMNR 2001, White et al. 2009). As a result, many jurisdictions have developed FTG survey procedures to evaluate the success of silvicultural treatments. These standards typically include a minimum height standard (e.g., Delaney et al. 2000, BCMF 2002, SEFS 2004, White et al. 2005, ASRD 2007).

Ontario's Forest Management Planning Manual defines FTG as, "stands that meet stocking, height, and/or height growth rate as specified in the [silvicultural] ground rules and are judged to be [healthy and] essentially free from competing vegetation" (OMNR 2004). Surveys are conducted to determine if individual trees have met free-growing status and if the stand contains sufficient numbers of well-distributed, freegrowing trees to be classified as FTG (ASRD 2007, White et al. 2009). The free-growing assessment of individual trees is based on crop tree species competitiveness, competitor to crop height ratio, competitor proximity to crop trees and competitor abundance (Pinto et al. 2003, White et al. 2005).

In Ontario the well-spaced free-growing regeneration assessment method (WSFG) (White et al. 2005) identifies the number of crop trees that are well-spaced, growing vigorously, and sufficiently free of competing vegetation. To determine free-growing status, a 1.2 metre radius "competition cylinder" (divided into four quadrants) is assessed around the crop tree. Crop trees are classified as not free-growing if: (1) woody competitors taller than half of crop tree height occur in at least one quadrant of the competition cylinder and more than one quadrant is occupied by either shrub or tree competitors, or (2) shrub competitors taller than two thirds of crop tree height occur in at least two quadrants and more than two quadrants are occupied by either shrub or tree competitors. The WSFG status is assessed seven to 11 years post-silviculture treatments when woody competition is assumed to exert a far greater negative effect on crop tree growth than herbaceous competition. It is assumed that crop trees that pass the free-growing criteria will continue to grow at reasonable rates and are likely to becoming a component of the canopy of the mature stand (White et al. 2005).

Alberta's FTG standards (ASRD 2007), which are based on minimum height standards, have recently been challenged by Lieffers et al. (2007). They analyzed two data sets and tested whether the FTG standards predicted the height increment of white spruce (Picea glauca [Moench.] Voss) saplings. Their results show that only $28 \%$ of the variation in height increment at age 18 was explained by height at age 13 and the addition of competition metrics did not substantially improve model fit. This suggests that after conifer growth is adjusted for initial differences in seedling height, adding competition variables to models does not improve predictions of subsequent growth. This result contradicts those of many vegetation management research trials that suggest herbaceous and woody competition negatively affect conifer growth (c.f. Wagner 2000, Balandier et al. 2006).

Wagner (2000) summarized results of experiments from across North America and concluded the consensus in the published literature was that during the initiation and the beginning of the stem-exclusion phases of plantation development ${ }^{6}$ herbaceous competition is more important than woody competition. Wagner (2000) noted that woody and

${ }^{6}$ For descriptions of plantation development phases used in this paper see Chen and Popadiouk (2002). herbaceous vegetation reduces the early volume growth potential of crop trees by about $20 \%$ to $30 \%$ and $70 \%$ to $80 \%$, respectively, underscoring the significant effects of herbaceous species on early growth. For coastal Douglas-fir (Pseudotsuga menziesii [Mirb.] Franco var menziesii), herbaceous competition typically dominates clearcuts immediately after harvest, but gives way to dominance by woody species within five years or so (Rose et al. 2006).

This change in dominance from herbaceous to woody species is assumed to occur in the boreal forests, but has yet to be documented. This lack of documentation may be attributed to the lack of published longer-term results ( $c f$. Wagner 2000). Balandier et al. (2006) summarized a global set of literature that indicated different effects on conifer growth related to various life forms of competitive species at different phases of stand development. They divided competitor species into broad groups: woody, large and small shrubs, graminoids, and forbs and assumed similar competitive effects and temporal patterns of competitiveness within each group. They suggested that graminoids and, to a lesser extent, forbs are more detrimental in the first few years of stand establishment, competing mostly for below-ground resources. Similarly, Man et al. (2008) reported that spot treatments (e.g., a 2-m radius of complete vegetation control around planted crop seedlings) could be a promising alternative to broadcast herbicide treatments for establishing spruce in mixedwood stands. In later phases of stand development, however, a considerable cover of herbaceous plants can exist without appreciable declines in forest yield. On the other hand, shrubs and trees compete for light and shrubs may significantly affect crop tree growth even after stand establishment. These effects were reported as relative rather than quantified and point to the importance of assessing the effects of herbaceous competition on early growth.

Based on published information (e.g., Wagner 2000, Balandier et al. 2006), the free-growing assessment rules used in Ontario that focus on the effects of small shrubs, large shrubs, and trees may require more consideration of the effects of herbaceous vegetation. While current standards may ensure that the planted seedlings occupy the site, they may not ensure those crop trees are free-to-grow if herbaceous competition significantly reduces growth. The objectives of this study were to analyze the effects of various classes of competitors on crop tree growth to improve the criteria used to classify crop trees as free-growing. The assumptions relevant to Ontario's FTG assessment standards were structured as a null hypothesis as follows:

$H_{o}$ : FTG standard based on crop tree height only: Accounting for woody and/or herbaceous competition does not explain the variation on crop tree growth during a specific time period.

The above-stated null hypothesis is based on the findings reported by Lieffers et al. (2007).

At least two alternative hypotheses are plausible: $H_{a 1}$ : FTG standard based on crop tree height plus woody competition: Accounting for woody competition explains the variation on crop tree growth during a specific time period.

$H_{a 2}:$ FTG standard based on crop tree height plus woody and herbaceous competition: Accounting for both herbaceous and woody competition explain the variation on crop tree growth during a specific time period. 
The first alternate hypothesis is based on current freegrowing assessment rules used in Ontario, which assume that once conifers have reached the sapling phase, herbaceous competition does not influence their growth (i.e., Pinto et al. 2003, White et al. 2005). The second alternate hypothesis is designed to identify the period during which the various classes of competitors significantly influence crop tree growth, as discussed in the summaries published by Wagner (2000) and Balandier et al. (2006). In all three hypotheses, we assume that conifer growth is adjusted to account for initial differences in tree size.

Since FTG is a concept that is widely accepted across North America, we believe the analytical approach applied here will be of interest to others developing and testing FTG standards. It also provides an opportunity to provide a quantifiable definition of FTG based on the reduction of growth potential resulting from the competitive effects of various groups of competitors.

\section{Methods}

The data used in this study were from a jack pine (Pinus banksiana Lamb.) and three black spruce (Picea mariana [Mill.] BSP) studies initiated under Ontario's Vegetation Management Alternatives Program (VMAP) (Wagner et al. 1994). The studies were randomized complete block designs established between 1990 and 1993 to compare the effectiveness of several methods of herbicide application (ground and aerial) and manual brushing to release individual planted jack pine and black spruce trees in the boreal and boreal/Great Lakes - St. Lawrence transition forests of Ontario. We tested the three hypotheses introduced above: that FTG standards based on (1) crop tree height only, (2) crop tree height plus woody competition, or (3) crop tree height plus woody and herbaceous competition best explain crop tree growth, using $10^{\text {th }}$-year post-treatment data collected from these studies and regression analysis.

\section{Description of jack pine study}

The E.B. Eddy jack pine study, established in 1993, is located approximately $90 \mathrm{~km}$ northeast of Espanola, Ontario $\left(46^{\circ} 48^{\prime} \mathrm{N} ; 82^{\circ} 11^{\prime} \mathrm{W}\right)$. The study includes three blocks and six treatments: (1) control (CON) - no tending; (2) brush saw (BS) - motor-manual cutting of all woody shrubs with brush saws in the fall; (3) basal bark/triclopyr (BBt) - basal bark application of triclopyr using backpack sprayers; (4) mist blower/glyphosate $(\mathrm{MBg})$ - ground application of glyphosate using backpack mist blower; (5) aerial spray/glyphosate (ASg) -aerial application of glyphosate via helicopter; and (6) continuous removal/glyphosate $(\mathrm{CRg})$ - three years of annual removal using foliar applications of glyphosate. Except for $\mathrm{ASg}$ and CRg treatments, which were $100 \mathrm{~m} \times 200 \mathrm{~m}$ and $40 \mathrm{~m} \times 40 \mathrm{~m}$ respectively, experimental units measured $50 \mathrm{~m}$ $\times 100 \mathrm{~m}$. The CRg treatment plot was randomly located within ASg treatment plots.

The original stands were representative of central Ontario ecosites (ES) 13.1 - jack pine, white pine (Pinus strobus L.), red pine (Pinus resinosa Ait.): dry to moderately fresh soils in block 1 , and 15.1 - jack pine: dry to moderately fresh soils in blocks 2 and 3 (Chambers et al. 1997). Prior to harvest, white pine dominated block $1\left(\mathrm{Pw}_{5} \mathrm{Pj}_{3} \mathrm{Po}_{2}\right)$ and jack pine dominated blocks $2\left(\mathrm{Pj}_{7} \mathrm{Sb}_{2} \mathrm{Po}_{1}\right)$ and $3\left(\mathrm{Pj}_{6} \mathrm{Sb}_{2} \mathrm{Po}_{2}\right)$. The white pine stand was approximately 150 years old and $24 \mathrm{~m}$ tall when harvested and the jack pine stands were 85 to 90 years old and 20 $\mathrm{m}$ to $21 \mathrm{~m}$ when harvested. The sites were clearcut in 1988 and 1989 and prepared with Young's teeth one year later. Block 1 was planted with current $\mathrm{FH}-408$ paperpot jack pine in 1989. Blocks 2 and 3 were planted with overwintered $\mathrm{FH}$ 408 paperpot and current-year 165 Jiffy pot jack pine, respectively, in 1991. Further details about the study site, treatments, and treatment efficacy are provided in Table 1 and Pitt et al. (2000). Stock size at the beginning of the study is summarized in Table 2.

Table 1. Description of study areas, treatments, and experimental designs, from which data for this study were compiled

\begin{tabular}{|c|c|c|c|c|c|c|c|c|}
\hline $\begin{array}{l}\text { Study } \\
\text { site }\end{array}$ & Location & $\begin{array}{l}\text { Soil } \\
\text { type }\end{array}$ & $\begin{array}{l}\text { Pre-harvest } \\
\text { vegetation cover }\end{array}$ & $\begin{array}{l}\text { Year } \\
\text { planted }\end{array}$ & $\begin{array}{l}\text { Year } \\
\text { released }\end{array}$ & $\begin{array}{l}\text { Sample } \\
\text { intensity } \\
\left(\mathrm{m}^{2} / \exp \text {. }\right. \\
\text { unit })\end{array}$ & Treatments $^{\mathrm{a}}$ & $\begin{array}{l}\text { Exp. design } \\
\text { (Exp. Units) }\end{array}$ \\
\hline Espanola & $\begin{array}{l}46^{\circ} 48^{\prime} \mathrm{N} \\
82^{\circ} 11^{\prime} \mathrm{W}\end{array}$ & $\begin{array}{l}\text { Fine sands } \\
\text { to silty } \\
\text { loams }\end{array}$ & $\begin{array}{l}\mathrm{B} 1: \mathrm{V} 18-\mathrm{Pj} / \mathrm{Sb} / \text { blueberry; } \\
\mathrm{B} 2 \text { and } \mathrm{B} 3: \mathrm{V} 17-\mathrm{Pj} / \mathrm{Sb} / \\
\text { feathermoss }^{\mathrm{b}}\end{array}$ & $\begin{array}{l}\text { Block 1: } 1989 \\
\text { Block } 2 \text { and 3: } \\
1991\end{array}$ & 1993 & 80 & $\begin{array}{l}\mathrm{CON}, \mathrm{BS}, \mathrm{BBt} \\
\mathrm{MBg}, \mathrm{ASg}, \mathrm{CRg}\end{array}$ & $\begin{array}{l}\text { RCBD: } \\
3 \text { blocks (18) }\end{array}$ \\
\hline Corrigal & $\begin{array}{l}49^{\circ} 01^{\prime} \mathrm{N} \\
88^{\circ} 10^{\prime} \mathrm{W}\end{array}$ & $\begin{array}{l}\text { Coarse } \\
\text { loam }\end{array}$ & V14- Bf mixedwood ${ }^{b}$ & 1988 & 1990 & 60 & $\begin{array}{l}\mathrm{CON}, \mathrm{BSg}, \mathrm{EZg} \\
\mathrm{BBt}, \mathrm{RHg}, \mathrm{CRg}\end{array}$ & $\begin{array}{l}\text { RCBD: } \\
3 \text { blocks (18) }\end{array}$ \\
\hline \multicolumn{9}{|l|}{ Leether } \\
\hline Lake & $\begin{array}{l}50^{\circ} 36^{\prime} \mathrm{N} \\
91^{\circ} 45^{\prime} \mathrm{W}\end{array}$ & $\begin{array}{l}\text { Coarse } \\
\text { loamy to } \\
\text { fine sand }\end{array}$ & $\begin{array}{l}\text { V17- Pj mixedwood / } \\
\text { shrub rich }\end{array}$ & 1988 & 1993 & 80 & $\begin{array}{l}\text { CON, BS, ASg, } \\
\text { CRg }\end{array}$ & $\begin{array}{l}\text { CRD: } \\
3 \text { blocks (12) }\end{array}$ \\
\hline Hele & $\begin{array}{l}48^{\circ} 59^{\prime} \mathrm{N} \\
88^{\circ} 33^{\prime} \mathrm{W}\end{array}$ & Fine loam & $\begin{array}{l}\text { V4- Bw hardwood } \\
\text { and mixedwood }\end{array}$ & 1987 & 1990 & 60 & $\begin{array}{l}\text { CON, SGh, } \\
\text { RHg, CRg }\end{array}$ & $\begin{array}{l}\text { RCBD: } \\
3 \text { blocks (12) }\end{array}$ \\
\hline
\end{tabular}

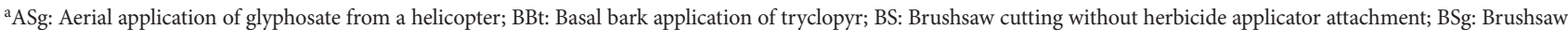
cutting with stump application of glyphosate CON: Untreated control; CRg: Continuous removal of vegetation by annual applications of glyphosate; EZg: EZ-Ject injection of glyphosate into competition basal stem; MBg: Backpack mist blower application of glyphosate; RHg: Reel and hose application of glyphosate; SGh: Spot gun application of hexazinone.

b(Chambers et al. 1997).

c(Sims et al. 1989).
} 
Table 2. Summary statistics for height and root collar diameter ( $\mathrm{rcd}$ ) at the beginning of stand development phase and for height, diameter at breast height (DBH), volume, and rcd at the end of stem-exclusion phase for jack pine and black spruce plantations in northern Ontario.

\begin{tabular}{|c|c|c|c|c|c|c|}
\hline Crop species (Site) & Variables & $\mathbf{N}$ & Mean & Std dev & Minimum & Maximum \\
\hline \multicolumn{7}{|c|}{ Beginning of stand initiation phase } \\
\hline Jack pine & height (cm) & 358 & 118 & 63 & 14 & 278 \\
\hline (E.B. Eddy) & $\operatorname{rcd}(\mathrm{mm})$ & 358 & 21 & 11 & 4 & 60 \\
\hline Black spruce & height $(\mathrm{cm})$ & 314 & 59 & 20 & 19 & 123 \\
\hline (Corrigal) & $\operatorname{rcd}(\mathrm{mm})$ & 314 & 10 & 3 & 3 & 23 \\
\hline Black spruce & height $(\mathrm{cm})$ & 238 & 102 & 39 & 26 & 213 \\
\hline (Leether lake) & $\operatorname{rcd}(\mathrm{mm})$ & 238 & 16 & 7 & 4 & 34 \\
\hline Black spruce & height $(\mathrm{cm})$ & 232 & 86 & 29 & 22 & 176 \\
\hline (Hele) & $\mathrm{rcd}(\mathrm{mm})$ & 232 & 13 & 5 & 4 & 26 \\
\hline \multicolumn{7}{|c|}{ End of stem-exclusion phase } \\
\hline Jack pine & height $(\mathrm{cm})$ & 317 & 555 & 123 & 201 & 845 \\
\hline \multirow[t]{2}{*}{ (E.B. Eddy) } & $\mathrm{DBH}(\mathrm{mm})$ & 317 & 75 & 23 & 10 & 134 \\
\hline & volume $\left(\mathrm{cm}^{3}\right)$ & 317 & 14449 & 9400 & 81 & 55724 \\
\hline Black spruce & height $(\mathrm{cm})$ & 308 & 308 & 125 & 45 & 583 \\
\hline \multirow[t]{3}{*}{ (Corrigal) } & $\mathrm{DBH}(\mathrm{mm})$ & 269 & 34 & 19 & 2 & 94 \\
\hline & volume $\left(\mathrm{cm}^{3}\right)$ & 308 & 3155 & 3619 & 2 & 20352 \\
\hline & $\operatorname{rcd}(\mathrm{mm})$ & 308 & 49 & 25 & 4 & 131 \\
\hline Black spruce & height $(\mathrm{cm})$ & 206 & 381 & 102 & 133 & 600 \\
\hline \multirow[t]{2}{*}{ (Leether lake) } & $\mathrm{DBH}(\mathrm{mm})$ & 206 & 38 & 16 & 1 & 80 \\
\hline & volume $\left(\mathrm{cm}^{3}\right)$ & 206 & 3021 & 2681 & 1 & 14789 \\
\hline Black spruce & height (cm) & 209 & 344 & 121 & 52 & 581 \\
\hline \multirow[t]{3}{*}{ (Hele) } & $\mathrm{DBH}(\mathrm{mm})$ & 195 & 41 & 20 & 2 & 92 \\
\hline & volume $\left(\mathrm{cm}^{3}\right)$ & 209 & 4613 & 4006 & 14 & 18637 \\
\hline & $\operatorname{rcd}(\mathrm{mm})$ & 209 & 61 & 25 & 10 & 120 \\
\hline
\end{tabular}

\section{Description of black spruce studies}

The Corrigal township site, established in 1990, is located 8 $\mathrm{km}$ east of Nipigon, Ontario. The study includes three blocks and six treatments (Table 1). All treatments included: (1) control (CON) - no tending; (2) brush saw (BS $)$ - motor-manual cutting using brush saws; (3) reel and hose/glyphosate (RHg) - directed foliar application of glyphosate; (4) EZ-Ject (EZg) - stem injection application of glyphosate; (5) basal bark/triclopyr (BBt) - thin-line application of triclopyr; and (6) continuous removal/glyphosate $(\mathrm{CRg})-5$ growing seasons of foliar applications of glyphosate. Treatments 2 to 5 were applied primarily to woody vegetation within an approximately $1-\mathrm{m}$ radius around each spruce tree. Treatment 6 was applied to all competing woody and herbaceous vegetation within a plot. Each treatment plot measures $60 \mathrm{~m}$ $\times 80 \mathrm{~m}$. The original stand was representative of V14 - balsam fir (Abies balsamea L.) mixedwood (Sims et al. 1989). The stand was site class 1 and the trees were approximately 61 years old when harvested. Balsam fir, black spruce, white birch (Betula papyrifera Marsh.) and white spruce occupied the site $\left(\mathrm{B}_{5} \mathrm{Sb}_{3} \mathrm{Bw}_{1} \mathrm{Sw}_{1}\right)$. The area was harvested in 1986 and 1987 using conventional cut-and-skid methods. It was site prepared in 1987 using a TTS disc trencher and planted in 1988 with black spruce bareroot seedlings at $2.2-\mathrm{m}$ to $3.0-\mathrm{m}$ spacing. Further details about the study site, treatments, and treatment efficacy are provided in Table 1 and Pitt et al. (2004). Stock size at the beginning of the study is summarized in Table 2.

The Leether Lake study, established in 1993, is located 56 $\mathrm{km}$ north of Sioux Lookout, Ontario $\left(50^{\circ} 36^{\prime} \mathrm{N} ; 91^{\circ} 45^{\prime} \mathrm{W}\right)$.
The study includes 3 blocks and 4 treatments (Table 1): (1) control (CON) - no tending; (2) brush saw (BS) - all competing woody vegetation was cut at ground level using brush saws between early and mid-June 1994; (3) aerial spray/glyphosate (ASg) - single application of glyphosate applied at $1.5 \mathrm{~kg}$ a.e. ha ${ }^{-1}$ from a helicopter on August 27 1993, and (4) continuous removal/glyphosate (CRg) - consisting of an operational single aerial treatment August 27, 1993, as per the ASg treatment, followed by two annual foliar backpack treatments with 2\% solution in 1994 through 1996.

The quantity of glyphosate applied by backpack spray varied depending on the abundance of vegetation that survived previous applications. Experimental units measured $60 \mathrm{~m} \times$ $80 \mathrm{~m}$. The original stand was representative of vegetation type 17 (V17), jack pine mixedwood shrub rich (Sims et al. 1989). It was fully stocked, dominated by jack pine with some trembling aspen (Populus tremuloides Michx.) and black spruce. The study area was harvested in 1987 when the stand was approximately 70 years old and $19 \mathrm{~m}$ tall. The site was prepared with light drags in fall 1987 and planted with black spruce bareroot stock in May and June 1988. When the study was initiated, black spruce seedlings averaged $85 \mathrm{~cm}$ tall and $12 \mathrm{~mm}$ in diameter at root collar. They were overtopped by trembling aspen with an average height of $206 \mathrm{~cm}$. The jack pine, which had regenerated from seed left on site after the harvest, averaged $90 \mathrm{~cm}$ tall. Low shrub and herbaceous plants occupied a large portion of the site. Foliar cover was primarily trembling aspen, bush honeysuckle (Diervilla lonicera Miller), large leaf aster (Eurybia macrophylla (L.) Cass.), fireweed (Chamerion angustifolium (L.) Holub ssp. 
angustifolium) and wild rose (Rosa acicularis Lindl. ssp. sayi (Schwein.) W. Lewis). Further details about the study site, and treatments are provided in Table 1 and stock size at beginning of our study in Table 2.

The Hele township site, established in 1990, is located 19 $\mathrm{km}$ west of Nipigon, Ontario $\left(48^{\circ} 59^{\prime} \mathrm{N} ; 88^{\circ} 33^{\prime} \mathrm{W}\right)$. This study includes three blocks and four treatments: (1) control (CON) - no tending, (2) reel and hose ( $\mathrm{RHg}$ ) - reel and hose application of glyphosate (1991), (3) spot gun (SGh) - spot gun application of hexazinone (1990), and (4) continuous removal/glyphosate (CRg) - two applications of glyphosate (1990, 1991). Each treatment plot measures $60 \mathrm{~m} \times 80 \mathrm{~m}$. The original stand was site class 1 to 2, representative of V4 white birch hardwood and mixedwood (Sims et al. 1989). It was dominated by white birch and balsam fir $\left(\mathrm{Bw}_{4} \mathrm{~B}_{3} \mathrm{Po}_{2} \mathrm{Sb}_{1}\right)$ that were 72 years old when harvested. The area was harvested in 1985 and 1986 and site-prepared in 1986 with a Bräcke scarifier ${ }^{\circledast}$. In 1987, the site was planted with bareroot black spruce. Further details about the study site, treatments, and treatment efficacy are provided in Table 1 and Pitt et al. (2004). Stock size at the beginning of the study is summarized in Table 2.

\section{Data collection}

Within each experimental unit, 20 representative crop tree seedlings were systematically located within a $40 \mathrm{~m} \times 60 \mathrm{~m}$ area in the centre of each treatment plot. Total height (nearest $\mathrm{cm}$, from groundline to the base of the terminal bud) and root collar diameter ( $\mathrm{rcd}$ ) (nearest $\mathrm{mm}, 1 \mathrm{~cm}$ above ground) of each seedling were recorded prior to treatment application between mid-July and early-August. Non-crop vegetation was assessed within a 1.13-m radius of each seedling's centre between mid-July and mid-August.

Horizontal percent cover and vertical heights were recorded for each species present using the following vegetation classes: (1) coniferous trees, (2) deciduous trees, predominantly trembling aspen, (3) tall/medium shrubs such as mountain maple (Acer spicatum Lamb.), beaked hazel (Corylus cornuta Marsh.), speckled alder (Alnus rugosa [Du Roi] Spreng.) and willow (Salix spp.), (4) low shrubs such as red raspberry (Rubus ideaus L.), (5) forbs, such as fireweed (Epilobium angustifolium L.) and large-leaved aster, (6) graminoids (including sedges and rushes), and (7) ferns, which were predominantly bracken fern.

Cover assessments were facilitated by placing two, 2.26-m lengths of plastic pipe in an " $X$ " over the subplot centre (i.e., the crop tree) and visually estimating the proportion of ground occupied by the vertical projection of crown(s) (to the nearest $5 \%$ ) for each quadrant. Trace amounts of vegetation were assigned $2 \%$ cover and total cover could add to more than $100 \%$ to accommodate structural layers.

All crop trees and vegetation subplots were assessed at the end of the growing seasons of 1994, 1995, 1996, 1998, and 2003 for jack pine and of 1991, 1992, 1993, 1995, and 2000 for black spruce. In the final measurement year, crown widths were recorded for each crop tree (one measure parallel to the planted row and a second perpendicular to the row). Crown area $\left(\mathrm{CA}, \mathrm{m}^{2}\right)$ was estimated from these measures, assuming an elliptical form (Zedaker and Miller 1991).

The gross total volumes of individual trees were calculated for black spruce and jack pine taller than breast height using equations developed by Honer et al. (1983). For the trees shorter than breast height, gross total volume was calculated by assuming the shape of the tree was a cone. Summary statistics of crop tree characteristics at age 12 are given in Table 2.

\section{Data analysis}

To examine the competition effect during the stand initiation phase $^{7}$, four years of individual crop tree volume and height growth (1994-1998 for jack pine, 1991-1995 for black spruce) were regressed against percent cover (horizontal) and mean height (vertical) of surrounding competitors at the beginning of the growth period (1991 for black spruce,1994 for jack pine). Similarly, the competition effect at the stemexclusion phase 8 was evaluated by regressing volume and height growth of each crop tree over a 5-year interval (1995-2000 for black spruce, 1998-2003 for jack pine) against horizontal (percent cover) and vertical (mean height) components of competitors at the beginning of the growth period (1995 for black spruce, 1998 for jack pine).

Variables resulting from quadratic transformations of horizontal and vertical components for each competitor were included in the regression to examine curvilinear effects of competitors on volume growth in each phase of stand development. The interaction effect of horizontal and vertical components of the competitors was evaluated by multiplying the components of competing vegetation under consideration (as appropriate based on the hypothesis being tested) and including them in the regression. Volumes and heights of crop trees at the beginning of growth period were used in the respective regressions as covariates. The stepwise regression method was applied in SAS (SAS Institute 2004) using FORWARD, BACKWARD, and MAXR (maximum $\mathrm{R}^{2}$ ) selection criteria to examine the importance of each horizontal, vertical, and their derived components for each competitor species in the regression.

\section{Results}

For both crop tree species on all sites, crop tree size at the beginning of the growth period (Table 2) explained the most variation in volume and height growth of crop trees during the stand initiation phase (i.e., two to six years post-plant). The coefficient of variation $\left(\mathrm{R}^{2}\right)$ for volume growth, with its initial value as the only regressor variable, ranged from 0.56 (black spruce at Hele) to 0.66 (black spruce at Corrigal). The coefficient of variation $\left(\mathrm{R}^{2}\right)$ for height growth, with its initial value as the only regressor variable, was lower than for volume, ranging from 0.08 (jack pine at E.B. Eddy) to 0.40 (black spruce at Corrigal).

Additional variables included in the models based on their contributions to increasing coefficient of variation (Table 3) depended on crop tree species and its characteristics (height and volume), and site. For example, for jack pine volume

\footnotetext{
${ }^{7}$ Stand initiation phase: colonization of the available free-growing space by trees following a stand-replacing disturbance (e.g., fire) (OMNR 2003).

${ }^{8}$ Stem-exclusion phase: the stage of stand development immediately following the stand initiation phase when all available growing space in the canopy is fully occupied by trees and competition occurs as individual trees expand in size (OMNR 2003).
} 
Table 3. Competition variables that significantly $(\alpha=0.05)$ influenced height growth and volume increases for jack pine and black spruce at different sites and time periods post-plant. Positive and negative signs indicate the nature of the regression coefficients.

\begin{tabular}{|c|c|c|c|c|c|c|c|c|}
\hline \multirow{3}{*}{$\begin{array}{l}\text { Order of } \\
\text { variables } \\
\text { entering } \\
\text { regression }\end{array}$} & \multirow{2}{*}{\multicolumn{2}{|c|}{$\begin{array}{l}\text { Jack pine } \\
\text { E.B. Eddy }\end{array}$}} & \multicolumn{6}{|c|}{ Black spruce } \\
\hline & & & \multicolumn{2}{|c|}{ Corrigal } & \multicolumn{2}{|c|}{ Leether Lake } & \multicolumn{2}{|c|}{ Hele } \\
\hline & $2-6 \mathrm{yr}$ & $7-12 \mathrm{yr}$ & $2-6 \mathrm{yr}$ & $7-12 \mathrm{yr}$ & $2-6 \mathrm{yr}$ & $7-12 \mathrm{yr}$ & $2-6 \mathrm{yr}$ & $7-12 \mathrm{yr}$ \\
\hline \multicolumn{9}{|l|}{ Stem height } \\
\hline $1^{\text {st }}$ & + In. ht. & + In. ht. & + In. ht. & + In. ht. & + In. ht. & + In. ht. & + In. ht. & + In. ht. \\
\hline $2^{\text {nd }}$ & $-\mathrm{BF}_{\mathrm{h}}^{2}$ & $-\mathrm{DT}_{\mathrm{c}}{ }^{*} \mathrm{DT}_{\mathrm{h}}$ & $-\mathrm{MS}_{\mathrm{h}}$ & $-\mathrm{DT}_{\mathrm{h}}^{2}$ & $-\mathrm{C}_{\mathrm{h}}$ & $-\mathrm{DT}_{\mathrm{h}}^{2}$ & $-\mathrm{DT}_{\mathrm{h}}$ & $-\mathrm{MS}_{\mathrm{c}}{ }^{\star} \mathrm{MS}_{\mathrm{h}}$ \\
\hline $3^{\text {rd }}$ & $-\mathrm{DT}_{\mathrm{h}}^{2}$ & $+\mathrm{F}_{\mathrm{c}}^{*} \mathrm{~F}_{\mathrm{h}}$ & $-\mathrm{DT}_{\mathrm{h}}$ & $-\mathrm{MS}_{\mathrm{c}}{ }^{\star} \mathrm{MS}_{\mathrm{h}}$ & $-G_{h}$ & - & $-\mathrm{MS}_{\mathrm{c}}{ }^{\star} \mathrm{MS}_{\mathrm{h}}$ & $-\mathrm{DT}_{\mathrm{h}}$ \\
\hline $4^{\text {th }}$ & - & $-\mathrm{G}_{\mathrm{h}}^{2}$ & $+\mathrm{C}_{\mathrm{c}}$ & $-\mathrm{DT}_{\mathrm{c}}{ }^{*} \mathrm{DT}_{\mathrm{h}}$ & $-\mathrm{F}_{\mathrm{c}}{ }^{*} \mathrm{~F}_{\mathrm{h}}$ & - & - & $-\mathrm{DT}_{\mathrm{c}}^{2}$ \\
\hline $5^{\text {th }}$ & - & - & $-\mathrm{C}_{\mathrm{c}}{ }^{2}$ & - & - & - & - & $+\mathrm{DT}_{\mathrm{c}}{ }^{\star} \mathrm{DT}_{\mathrm{h}}$ \\
\hline In. ht $\mathrm{R}^{2}$ & 0.08 & 0.13 & 0.40 & 0.37 & 0.33 & 0.35 & 0.28 & 0.30 \\
\hline Total $\mathrm{R}^{2}$ & 0.20 & 0.26 & 0.46 & 0.55 & 0.50 & 0.42 & 0.32 & 0.64 \\
\hline Diff $\mathrm{R}^{2}$ & 0.12 & 0.13 & 0.06 & 0.18 & 0.17 & 0.07 & 0.04 & 0.34 \\
\hline \multicolumn{9}{|l|}{ Stem volume } \\
\hline & + In. vol. & + In. vol. & + In. vol. & + In. vol. & + In. vol. & + In. vol. & + In. vol. & + In. vol. \\
\hline $2^{\text {nd }}$ & $-\mathrm{DT}_{\mathrm{h}}$ & $-\mathrm{DT}_{\mathrm{c}}{ }^{*} \mathrm{DT}_{\mathrm{h}}$ & $-\mathrm{DT}_{\mathrm{c}}$ & $+\mathrm{F}_{\mathrm{c}}$ & $-C_{h}$ & $-\mathrm{DT}_{\mathrm{h}}^{2}$ & $-\mathrm{MS}_{\mathrm{h}}$ & $-\mathrm{MS}_{\mathrm{h}}$ \\
\hline $3^{\text {rd }}$ & $-\mathrm{F}_{\mathrm{h}}$ & $+\mathrm{BF}_{\mathrm{c}}$ & $+\mathrm{DT}_{\mathrm{c}}{ }^{\star} \mathrm{DT}_{\mathrm{h}}$ & $-\mathrm{F}_{\mathrm{c}}^{2}$ & $-\mathrm{DT}_{\mathrm{c}}$ & $+\mathrm{DT}_{\mathrm{h}}$ & $-\mathrm{DT}_{\mathrm{h}}$ & $+\mathrm{MS}_{\mathrm{h}}^{2}$ \\
\hline $4^{\text {th }}$ & $-\mathrm{BF}_{\mathrm{h}}$ & $-\mathrm{BF}_{\mathrm{c}}^{2}$ & $-G_{h}$ & $-\mathrm{MS}_{\mathrm{c}}{ }^{*} \mathrm{MS}_{\mathrm{h}}$ & $-\mathrm{F}_{\mathrm{c}}$ & $-C_{h}$ & $-\mathrm{F}_{\mathrm{h}}$ & $-\mathrm{DT}_{\mathrm{c}}$ \\
\hline $5^{\text {th }}$ & $-G_{h}$ & $-\mathrm{BF}_{\mathrm{h}}$ & $+\mathrm{F}_{\mathrm{c}}$ & $-\mathrm{DT}_{\mathrm{c}}$ & $-\mathrm{DT}_{\mathrm{h}}$ & $+\mathrm{F}_{\mathrm{h}}$ & $+\mathrm{F}_{\mathrm{h}}^{2}$ & $-\mathrm{MS}_{\mathrm{c}}{ }^{\star} \mathrm{MS}_{\mathrm{h}}$ \\
\hline $6^{\text {th }}$ & $-\mathrm{DT}_{\mathrm{c}}{ }^{*} \mathrm{DT}_{\mathrm{h}}$ & $+\mathrm{F}_{\mathrm{c}}^{*} \mathrm{~F}_{\mathrm{h}}$ & $+\mathrm{G}_{\mathrm{h}}^{2}$ & $-\mathrm{DT}_{\mathrm{h}}$ & $+\mathrm{DT}_{\mathrm{c}}^{2}$ & - & - & - \\
\hline $7^{\text {th }}$ & - & $+\mathrm{G}_{\mathrm{h}}$ & $-\mathrm{DT}_{\mathrm{h}}^{2}$ & - & $-\mathrm{G}_{\mathrm{h}}^{2}$ & - & - & - \\
\hline $8^{\text {th }}$ & - & $-G_{h}^{2}$ & $-\mathrm{F}_{\mathrm{c}}^{2}$ & - & $+\mathrm{MS}_{\mathrm{h}}^{2}$ & - & - & - \\
\hline $9^{\text {th }}$ & - & - & $-\mathrm{LS}_{\mathrm{c}}{ }^{\star} \mathrm{LS}_{\mathrm{h}}$ & - & $+\mathrm{F}_{\mathrm{c}}^{2}$ & - & - & - \\
\hline In. vol. $\mathrm{R}^{2}$ & 0.60 & 0.55 & 0.66 & 0.60 & 0.60 & 0.59 & 0.56 & 0.70 \\
\hline Total $\mathrm{R}^{2}$ & 0.71 & 0.62 & 0.70 & 0.69 & 0.71 & 0.64 & 0.61 & 0.80 \\
\hline Diff $\mathrm{R}^{2}$ & 0.11 & 0.07 & 0.04 & 0.09 & 0.11 & 0.05 & 0.05 & 0.10 \\
\hline
\end{tabular}

Legend:

In. vol. = volume of crop tree at beginning of growth period

In. ht. = height of crop tree at beginning of growth period

$$
\begin{array}{ll}
\text { Percent cover: } & \text { Mean height: } \\
\mathrm{C}_{c}=\text { coniferous trees } & \mathrm{C}_{\mathrm{h}}=\text { coniferous trees } \\
\mathrm{DT}_{c}=\text { deciduous trees } & \mathrm{DT}_{\mathrm{h}}=\text { deciduous trees } \\
\mathrm{MS}_{\mathrm{c}}=\text { medium shrubs } & \mathrm{MS}_{\mathrm{h}}=\text { medium shrubs } \\
\mathrm{LS}_{\mathrm{c}}=\text { low shrubs } & \mathrm{LS}_{\mathrm{h}}=\text { low shrubs } \\
\mathrm{G}_{\mathrm{c}}=\text { graminoids } & \mathrm{G}_{\mathrm{h}}=\text { graminoids } \\
\mathrm{F}_{\mathrm{c}}=\text { forbs } & \mathrm{F}_{\mathrm{h}}=\text { forbs } \\
\mathrm{BF}_{\mathrm{c}}=\text { bracken fern } & \mathrm{BF}_{\mathrm{h}}=\text { bracken fern }
\end{array}
$$

Superscript 2 in these variables represents the quadratic transformation.

growth at the E.B. Eddy site, the second- and third-most important variables were the mean heights of deciduous tree species and forbs, respectively. However, for jack pine height growth at the same site, the second- and third-most important variables were the mean height of bracken fern and deciduous tree species, respectively.

In contrast, for black spruce volume growth at Corrigal, the second- and third-most important variables in the regres- sion were the horizontal percent cover and the interaction of percent cover and mean height of deciduous trees, respectively. The most important variables for the Leether Lake site were the mean height of the coniferous species and the horizontal percent cover of deciduous trees, respectively. Similarly, the second- and third-most important variables at Hele were the mean heights of medium shrubs and deciduous trees, respectively. 
All variables that contributed significantly $(\alpha=0.05)$ to explaining the variation in the volume and height growth in the initiation phase are presented in Table 3 along with overall coefficients of determination $\left(\mathrm{R}^{2}\right)$. Effects of the variables on volume and height growth are indicated by positive and negative signs.

In the early part of the stem-exclusion phase (seven to 12 years post-plant) of plantation development, all three stepwise regression selection methods (FORWARD, BACKWARD, and MAXR) provided consistent results: the most important variable for explaining differences in volume and height growth of crop trees was their initial size. The coefficient of variation $\left(R^{2}\right)$ for volume growth, with its initial value as the only regressor variable, ranged from 0.55 (jack pine at E.B. Eddy) to 0.70 (black spruce at Hele). Similarly, the coefficient of variation $\left(\mathrm{R}^{2}\right)$ for height growth, with its initial value as the only regressor variable, ranged from 0.26 (jack pine at E.B. Eddy) to 0.64 (black spruce at Hele).

However, competition variables that affected this later phase of stand development differed from those in the initiation phase but additional variables included in the model still depended on the crop tree species and characteristics (volume and height), and site. For example, the second- and third-most important variables for volume growth for jack pine at the E.B. Eddy site were the interaction between horizontal percent cover and mean height of deciduous trees, and the horizontal percent cover of bracken fern, respectively. Similarly, the second-and third-most important variables for height growth at that site were the interaction between horizontal percent cover and mean height of deciduous trees and the interaction between the horizontal percent cover and mean height of forbs, respectively.
During the stem-exclusion phase, horizontal percent cover of forbs and their quadratic transformation were the secondand third-most important variables, respectively, in the regression for volume growth of black spruce at Corrigal. Quadratic transformations of the mean height of deciduous trees and their linear term were the second- and third-most important variables, respectively, at Leether Lake. Similarly, the mean heights of medium shrubs and their quadratic transformation were the second-and third-most important variables, respectively, at Hele.

Other variables that were significant $(\alpha=0.05)$ in explaining the variation in the volume growth at the stem-exclusion phase are presented in Table 3. All the variables that were significant in explaining the height growth at all sites during the stand initiation phase are also provided in Table 3. Positive and negative signs for the regression coefficients are presented in the table along with overall values for the coefficient of determination $\left(\mathrm{R}^{2}\right)$.

The coefficients for the initial values for both volume and height were positive for both species at all sites for both growth periods. This implies that the larger and taller a tree is at the beginning of growth period the more volume and height growth that can be expected for both species thereafter. Effects of other variables depended on tree species, its characteristics, the site, and length of the growth period. For example, forbs on the Hele site had negative curvilinear effects and the other three important variables had negative linear effects on volume growth of black spruce trees. Similarly, most of the competition variables for the Corrigal and the Leether Lake sites negatively affected volume growth of black spruce trees during the stand initiation phase.

During the stem-exclusion phase, horizontal percent
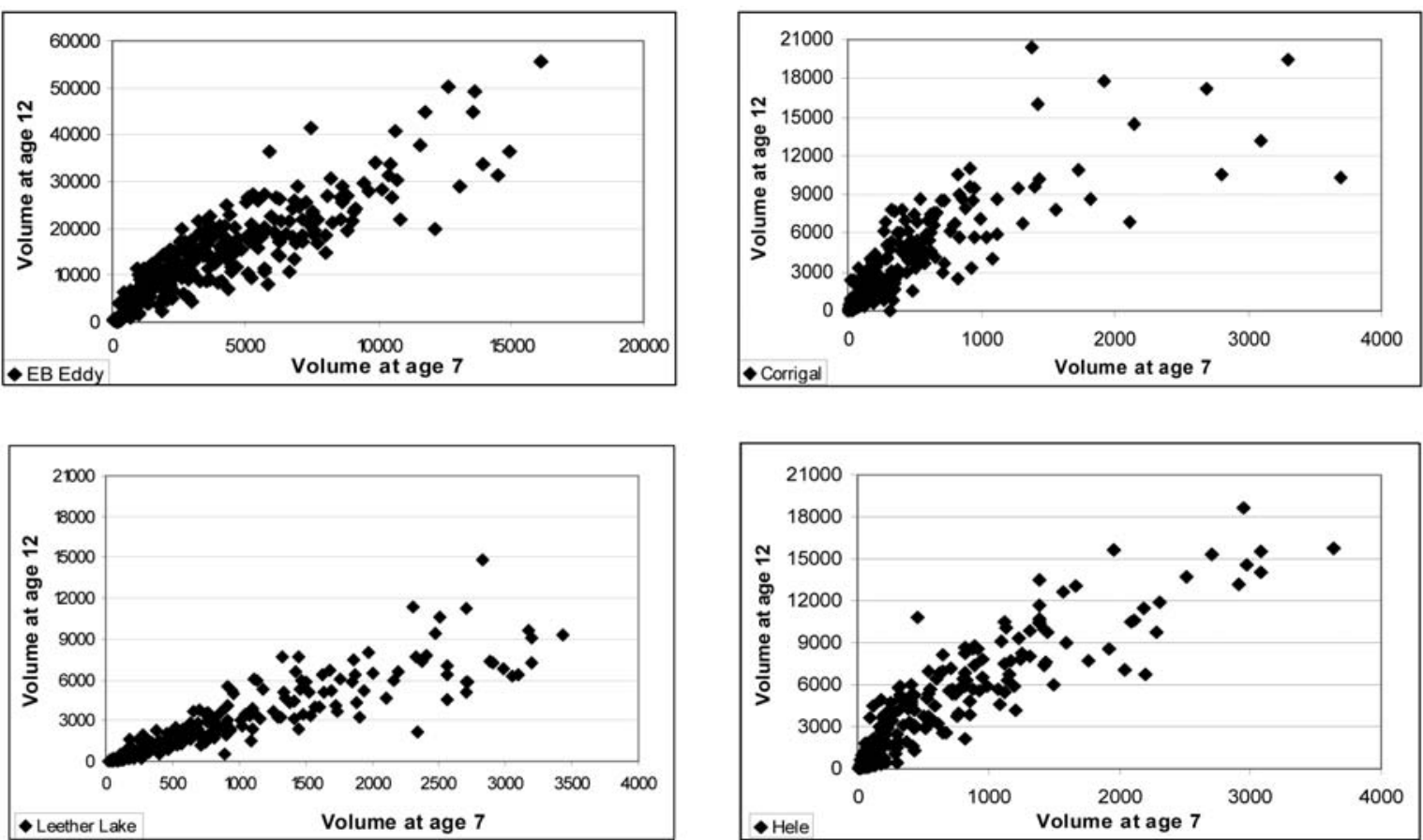

Fig. 1. Individual tree volumes $\left(\mathrm{cm}^{3}\right.$ ) at age 12 plotted against their volumes at age 7 for crop trees at different sites (jack pine at E.B. Eddy, black spruce at Corrigal, Leether Lake, and Hele). 
cover of forbs had a positive curvilinear effect on volume growth of black spruce at the Corrigal site while the mean height of medium shrubs had a negative curvilinear effect at the Hele site. The rest of the competition variables for these sites had negative linear effects on volume growth. At the Leether Lake site, the mean height of deciduous trees had a positive curvilinear effect, the mean height of coniferous trees had negative linear effect, and the mean height of forbs had positive linear effect on tree height growth. Similarly, horizontal percent cover of bracken ferns and mean height of graminoids had a positive curvilinear effect, mean height of bracken ferns and the interactions of deciduous tree components had negative linear effects, and the interaction of forbs components had a positive linear effect on the volume growth of jack pine trees. The effects of competitor species on target tree height growth are summarized in Table 3.

To visually examine the effect of initial size, total volumes at age 12 were plotted against total volumes at age 7 (Fig. 1). Similarly, the effects of competition are shown by plotting volume growth between ages 7 and 12 against competition variables at age 7 (Fig. 2 to Fig. 4). Given the high variability associated with the competition variables, initial volume was decidedly more important than other competition variables in explaining volume growth for both species. Similar patterns were found for height growth (not shown).

\section{Discussion}

We examined effects of woody and herbaceous vegetative competition on height and volume growth of two species of conifers within two time periods across a variety of vegetation management treatments. Using only initial height as the predictive variable, our models explained $28 \%$ to $40 \%$ of the variation in height growth of black spruce. The addition of competition metrics explained an additional $4 \%$ to $34 \%$ of the variation in growth (Table 3). For jack pine, height alone accounted for $8 \%$ to $13 \%$ of the variation in height growth and the addition of competition metrics explained an additional $12 \%$ to $13 \%$.

In our volume growth model, initial size accounted for $55 \%$ to $70 \%$ of volume growth over the two phases of stand development considered. After accounting for initial volume, competition explained an additional $4 \%$ to $11 \%$ of the variation in volume growth. The addition of the competition metrics significantly, albeit in some cases not substantially, improved the fit statistics for both tree height and volume growth models for black spruce and jack pine for both time periods for a variety of upland site conditions. Cortini and Comeau (2008) reported that tree, tall shrub, and herbaceous cover influenced the growth of white spruce whereas tall shrubs were the major competitors for lodgepole pine (Pinus contorta Dougl.). Our study also indicated that the competi-

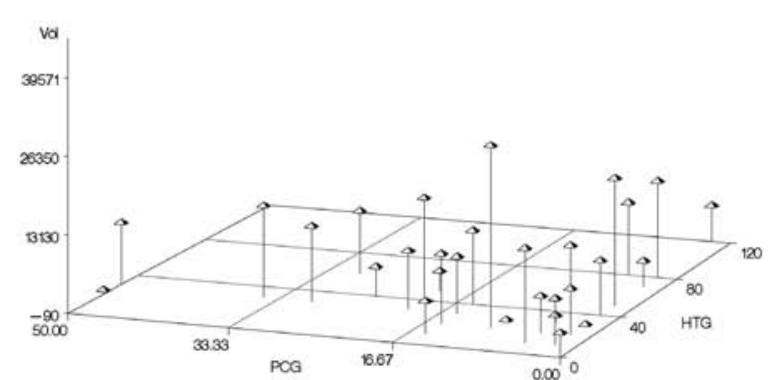

Vo: Volume growth tram age 7 to 12 yt, POC: Graminaid percent cover, and $H T Q$ Graminaid mean heght Site EB Eddy

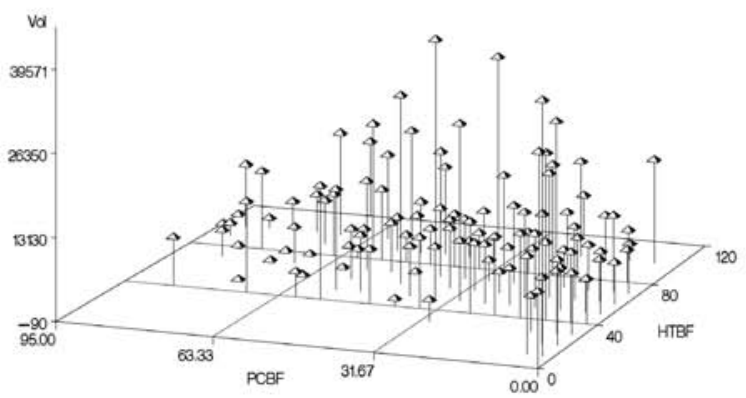

Vo: Volume growth trom age 7 to $12 \mathrm{yc}$, PCBP. Bracken fem percent cover, and HTBP. Bracken fem mean height Site: EB Eddy

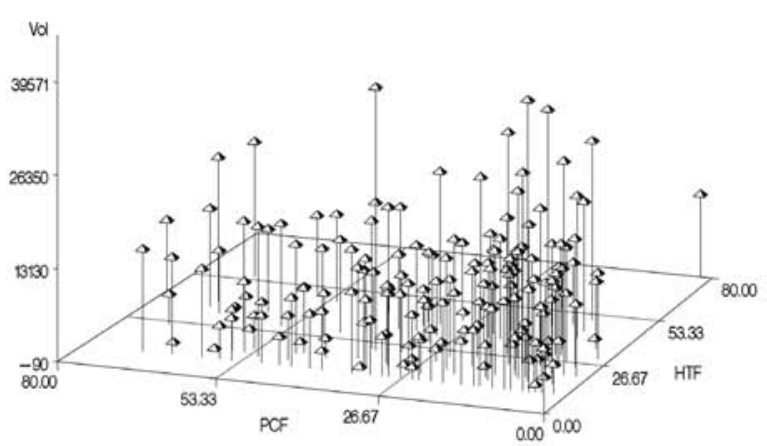

Vo: Volume grown trom age 7 to 12 yr, PCF. Foro percent cover, and HTF. Fơr mean height Siter EB Eddy

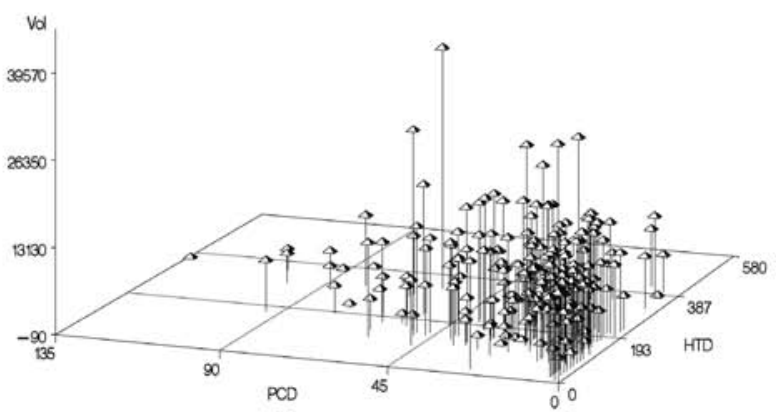

Va: Volume growh from age 7 to 12 y, PCD. Deciduous tree percent cover, and HTD. Deciduous tree mean heigh Site: EB Eddy

Fig. 2. Individual tree volumes plotted against percent covers and mean heights of selected competitor species that were significant in the regressions of volume growth for jack pine at EB Eddy. 


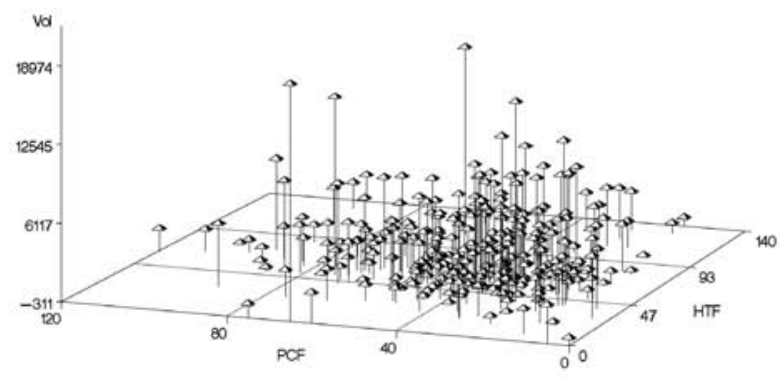

Vol: Volume growth trom age 7 to $12 \mathrm{y}$, PCF. Forb percent cover, and HTF. Forb mean height Sace. Comigat

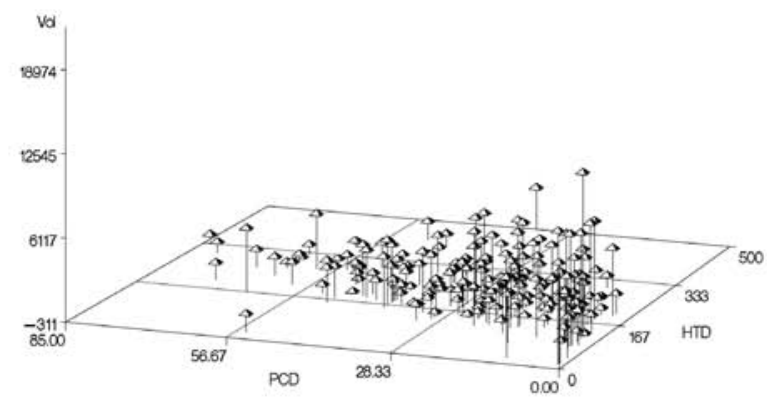

Vo: Volume grawth from age 7 to 12 y. PCD. Deciduous tree percent cover, and HTD: Deciduous tree mean height Site Comigal

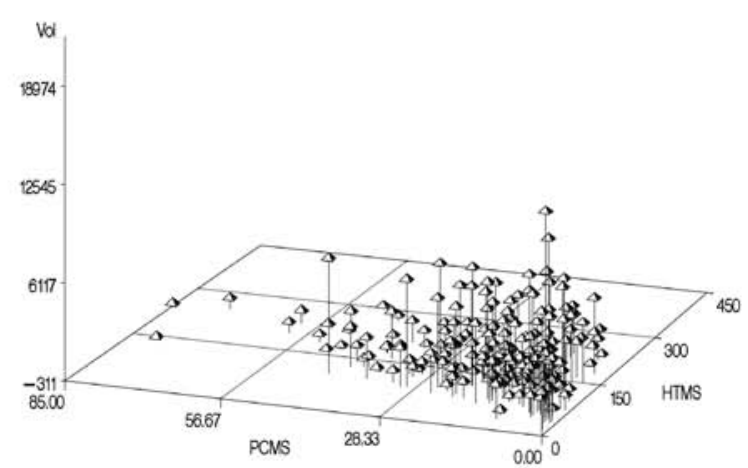

Vo: Volume growen from age 7 to $12 \mathrm{yc}$, PCMS: Nedum strub percent cover, and HTMS: Medum strub mean height Site: Corrigal

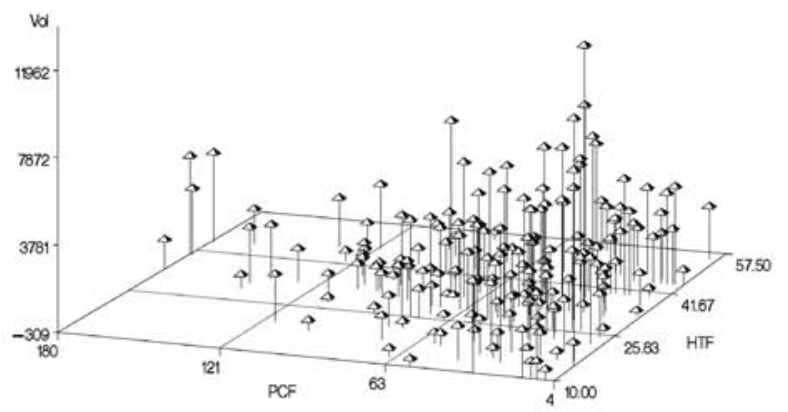

Vol: Volume grown trom age 7 io $12 \mathrm{yr}$, PCF, Forb percent cover, and HTF. Foro mean height Site. Leether lake

Fig. 3. Individual tree volumes plotted against percent covers and mean heights of selected competitor species that were significant in the regressions of volume growth for black spruce at different sites.

tion effects of different competitors depended on the crop tree species, its characteristics (volume and height), and site differences.

The results of our study are similar to those of previous studies indicating that stem diameter and volume are more sensitive indicators of competition than height (Brand and Janas 1988, Jobidon et al. 1998, Morris et al. 1990, Longpré et al. 1994, Wagner et al. 1996, Pitt et al. 1999, Bell et al. 2002). As well, frost and insects that destroy the terminal shoot will affect volume less than height. Thus, in operational field assessments, criteria for deciding which trees will perform best in the future should be based on both tree height and diameter.

Depending on the timing of FTG assessments, including estimates of herbaceous cover may or may not be necessary. Free-to-grow surveys are commonly carried out between five and 10 years after planting, which corresponds to the start of the stem-exclusion phase of plantation development, particularly if natural regeneration of aspen is not controlled on sites where it occurs. Current standards for FTG surveys in Ontario do not consider herbaceous vegetation as significant competitors (White et al. 2005), unless the herbs are taller than the crop tree (Pinto et al. 2003). However, our results suggest that regeneration surveys done in the stand initiation phase of development (two to six years post-plant) should include herbaceous vegetation as competition. These results are supported by much of the recently published literature as summarized by Wagner (2000) and Balandier et al. (2006).

Wagner (2000) reviewed the results of experiments designed to separate the competitive influence of woody and herbaceous vegetation in the U.S. Pacific Northwest (Petersen and Newton 1985; Wagner and Radosevich 1998), southeast (Miller et al. 1991, Zutter et al. 1995, Zutter and Miller 1998, Cain 1999), Lake States (Nichols et al. 1995), and Ontario (Bell et al. 2002) and found consensus among the results: herbaceous competition is more important than woody competition during the initiation phase of plantation development. These results suggest that herbaceous vegetation alone reduces the early volume growth potential of crop trees by $70 \%$ to $80 \%$ (Wagner 2000). However, in the stem-exclusion phase, woody species were found to have a greater effect on Douglas fir (Rose et al. 2006) and, as observed in this study, on jack pine and black spruce height and volume growth.

Balandier et al. (2006) hypothesized that during later phases of stand development, a considerable number, cover, or density of herbaceous plants can exist in forest stands without appreciable (detectable) declines in crop tree growth. Evidence from this study largely supports that hypothesis. However, we found that the negative effects of herbaceous competition diminished far earlier than anticipated. Also, 


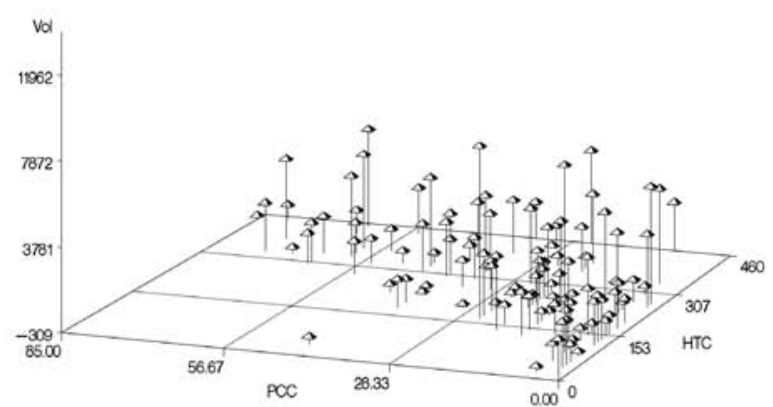

Vol: Volume growth from age 7 to $12 \mathrm{yc}, \mathrm{PCC}$. Coniforous tree peroent cover, and HTC: Coriforous troe mean height Site, Leether lake

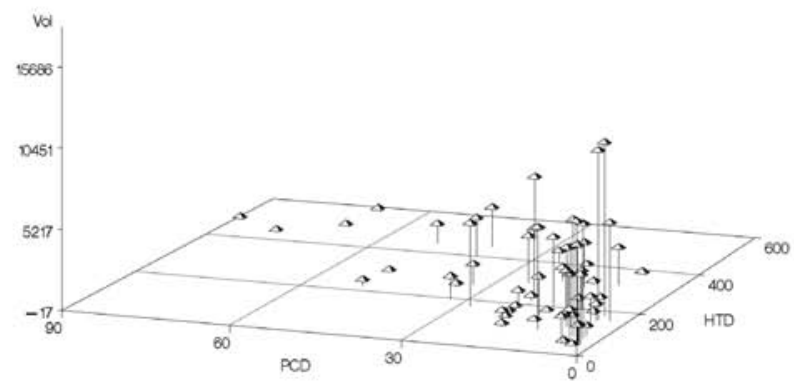

Vol: Voume grower from age 7 to 12 y, PCD: Deciducus tree percent cover, and HTD. Deciduous tree mean height Siter. Hele

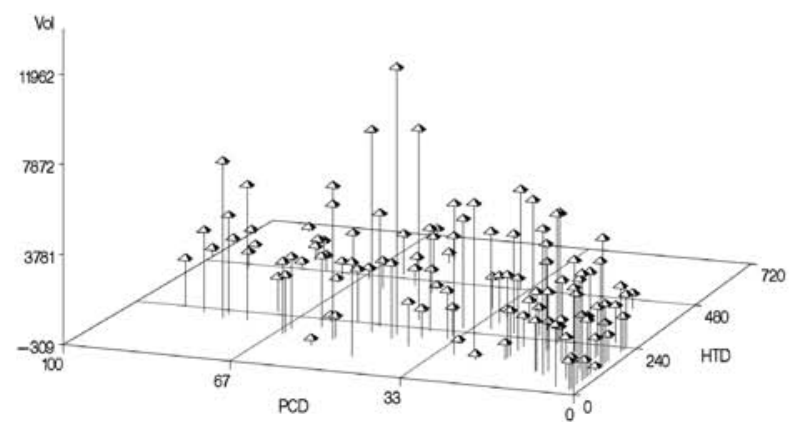

Vo: Volume growth from age 7 to $12, y, P C D$. Deciduous tree percent cover, and HTD. Deciduous tree mean height Siter. Lecther lake

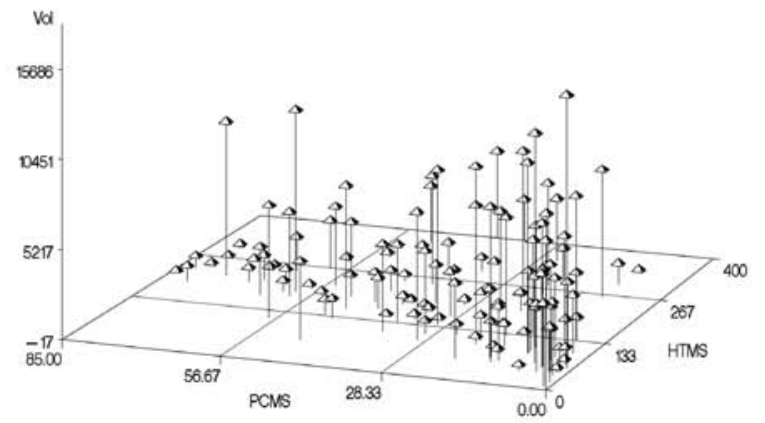

Vo: Volume growh trom age 7 to 12 y, PCNS: Medum sinb percent cover, and HTMS: Mecium shib meen height Siter Hele

Fig. 4. Individual tree volumes plotted against percent covers and mean heights of selected competitor species that were significant in the regressions of volume growth for black spruce at different sites.

herbaceous cover was positively correlated with conifer growth in the stem-exclusion phase of development.

From the results of this research and a review of the literature it is clear that estimates of height and the abundance of woody competition need to be included in FTG surveys. The decision to include estimates of herbaceous competition in FTG surveys will depend on the height of the crop trees in relation to the height of the herbaceous competitors at the time of assessment. If the crop trees are small, herbaceous cover should be assessed. When FTG assessments are scheduled later (i.e., seven to 11 years post-renewal), herbaceous competition can be excluded from assessments to determine the free-growing status of black spruce and jack pine crop trees, at least in Ontario's boreal and boreal/Great Lakes - St. Lawrence transition forest (Pinto et al. 2003, White et al. 2005).

Silvicultural practices, such as planting large stock or early control of competing vegetation (including herbaceous species), will affect the time it takes plantations to reach FTG. In this study and in that reported by Lieffers et al. (2007), initial size accounted for most of the variation in crop tree height and volume growth. These findings are not unexpected. Evidence from numerous nursery outplant trials support planting large stock to reduce the effects of competition on growth and survival of Picea sitchensis (Bong.) Carrière (South and Mason 1993), P. mariana (Jobidon et al. 1998, 2003), Pinus elliottii Engelm. (South and Mitchell 1999), P. radiata D. Don
(Mason et al. 1996), and Pseudotsuga menziesii (Newton et al. 1993). Jobidon et al. (2003) also showed that growth gains from combining planting large stock with vegetation control were multiplicative. In this study, relatively small planting stock was used (i.e., FH-408 paperpot and 165 Jiffy pot). Effects of competition on conifer growth may have been reduced if larger stock had been used.

\section{Conclusions}

We conclude that crop tree height alone is not a good predictor of free-to-grow status for jack pine or black spruce. Instead, results from our study support both our alternate hypotheses. During the stand initiation phase, accounting for initial differences in crop tree size as well as size and abundance of herbaceous and woody competition significantly explained $(p \leq 0.05)$ the variation on the growth of crop trees for both jack pine and black spruce. During the stem-exclusion phase, accounting for initial differences in crop tree size as well as size and abundance of woody competition significantly explained $(p \leq 0.05)$ the variation on the growth of crop trees for both species. This is consistent with current free-growing assessment rules used in Ontario that assume herbaceous competition does not significantly decrease conifer growth after they have reached the stem-exclusion phase.

Our results also suggest that tree volume may be a better predictor of future tree performance than height or height 
growth. This provides indirect support for planting large seedlings when regenerating sites where intense competition from other species is expected. Although height is commonly used as an indicator of conifer performance in FTG surveys, compared to diameter or volume growth height growth has consistently proven relatively insensitive to competition. Including diameter or volume as a metric in free-to-grow surveys may provide more accurate estimates of competition effects on conifer growth. These results are relevant to forest managers who are developing and/or using FTG survey procedures.

\section{Acknowledgements}

The data collections used in this study were supported in part by the Ontario Ministry of Natural Resources, Forestry Research Partnership, Living Legacy Trust, and Forestry Futures Trust. The authors are grateful to the many individuals who co-ordinated the installation of the field studies including Chris Hollstedt and Phil Bunce and/or who led data collections including Ago Lehela, Amy Bolduc, Dan Arcand, Dianne Othmer, Kate Woods (ne Jacobs), Paul Bastarache, and Rob Foster. The authors also extend thanks to Frank Schnekenburger (Spatialworks) and Nirmal Subedi (OFRI) for their assistance in compiling the data and conducting preliminary analyses and Lisa Buse (OFRI) for editing the manuscript. Four anonymous reviewers provided helpful comments on earlier versions of the manuscript.

\section{References}

[ASRD] Alberta Sustainable Resource Development. 2007. Alberta regeneration survey manual. Alberta Forest Management Br., Edmonton, AB. 55 p. + append.

Balandier, P., C. Collet, J.H. Miller, P.E. Reynolds and S.M. Zedaker. 2006. Designing forest vegetation management strategies based on the mechanisms and dynamics of crop tree competition by neighbouring vegetation. Forestry 79: 3-27.

[BCMF] British Columbia Ministry of Forests. 2002. Stocking and free-growing survey procedures manual. B.C. Min. For., Forest Practices Branch, Victoria, BC. 119 p.

Bell, F.W., M.T. Ter-Mikaelian and R.G. Wagner. 2002. Relative competitiveness of nine early-successional boreal forest species associated with planted jack pine and black spruce seedlings. Can. J. For. Res. 30: 790-800.

Brand, D.G. and P.S. Janas. 1988. Growth and acclimation of planted white pine and white spruce seedlings in response to environmental conditions. Can. J. For. Res. 18: 320-329.

Cain, M.D. 1999. Woody and herbaceous competition effects on stand dynamics and growth of 13-year-old natural, precommercially thinned loblolly and shortleaf pines. Can. J. For. Res. 29: 947-959.

Chambers, B.A., B.J. Naylor, J. Nieppola, B. Merchant and P. Uhlig. 1997. Field guide to forest ecosystems of central Ontario. Ont. Min. Nat. Resour., Southcentral Sci. Sect., North Bay, ON. SCSS Field Guide FG-01.

Chen, H.Y.H. and R.V. Popadiouk. 2002. Dynamics of North American boreal mixedwoods. Environ. Rev. 10: 137-166.

Cortini, F. and P.G. Comeau. 2008. Evaluation of competitive effects of green alder, willow and other tall shrubs in Northern Alberta. For. Ecol. Manage. 255: 82-91.

Delaney, J.R., T. Ringash and D. Auer. 2000. Manitoba free to grow survey manual. Manitoba Conserv., For. Br., Winnipeg, MB. 35 p.

Gwaze, D., M. Johanson and C. Hauser. 2007. Long-term soil and shortleaf pine responses to site preparation ripping. New For. 34: 143-152.

Honer, T.G., M.F. Ker and I.S. Alemdag. 1983. Metric timber tables for the commercial tree species of central and eastern Canada. Can.
For. Serv., Maritimes For. Res. Centre, Fredericton, NB. Info. Rep. $\mathrm{M}-\mathrm{X}-140$.

Jacobs, D.F., A.L. Ross-Davies and A.S. Davis. 2004. Establishment success of conservation tree plantations in relation to silvicultural practices in Indiana, USA. New For. 28: 23-36.

Jain, T.B., R.T. Graham and P. Morgan. 2004. Western white pine growth relative to forest openings. Can. J. For. Res. 34: 2187-2198.

Jobidon, R., L. Charette and P.Y. Bemier. 1998. Initial size and competing vegetation effects on water stress and growth of Picea mariana (Mill.) BSP seedlings planted in three different environments. For. Ecol. Manage. 103: 293-305.

Jobidon, R, V. Roy and G. Cyr. 2003. Net effect of competing vegetation on selected environmental conditions and performance of four spruce seedling stock sizes after eight years in Québec (Canada). Ann. For. Sci. 60: 691-699.

Lieffers, V.J., K.J. Stadt and Z. Feng. 2007. Free-to-grow regeneration standards are poorly linked to growth of spruce in boreal mixedwoods. For. Chron. 83(6): 818-824.

Longpré, M.-H., Y. Bergeron and D. Paré. 1994. Effect of companion species on the growth of jack pine (Pinus banksiana). Can. J. For. Res. 24: 1846-1853.

Man, C.D., P.G. Comeau and D. Pitt. 2008. Competitive effects of woody and herbaceous vegetation in a young boreal mixedwood stand. Can. J. For. Res. 38: 1817-1828.

Mason, E.G., D.B. South and Z. Weizhong. 1996. Performance of Pinus radiata in relation to seedling grade, weed control, and soil cultivation in the central North Island of New Zealand. N.Z. J. For. Sci. 26: 173-183.

Miller, J.H., B.R. Zutter, S.M. Zedaker, M.B. Edwards, J.D. Haywood and R.A. Newbold. 1991. A regional study on the influence of woody and herbaceous competition on early loblolly pine growth. South. J. Appl. For. 15: 169-179.

Morris, D.M., G.B. MacDonald and K.M. McClain. 1990. Evaluation of morphological attributes as response variables to perennial competition for 4-year-old black spruce and jack pine seedlings. Can. J. For. Res. 20: 1696-1703.

Newton, M., E.C. Cole and D.E. White. 1993. Tall planting stock for enhanced growth and domination of brush in the Douglas-fir region. New For. 7: 107-121.

Nichols, T.J., L.C. Peterson and J. Trobaugh. 1995. Effects of woody and herbaceous competition on the early growth of white spruce and red pine. Abstract presented at 49th Ann. Meet. Northeast Weed Sci. Soc., Boston, MA. 2-5 Jan. 1995.

[OMNR] Ontario Ministry of Natural Resources. 2001. Silvicultural effectiveness monitoring manual for Ontario. Ont. Min. Nat. Resour., Toronto, ON. 42 p.

2003. Silviculture guide to managing spruce, fir, birch, and aspen mixedwoods in Ontario's boreal forest. Version 1.0. Ont. Min. Nat. Resour., Toronto, ON. 286 p. + append.

2004. Forest Management Planning Manual for Ontario's Crown Forests. Ont. Min. Nat. Resour., Toronto, ON. 440 p.

Petersen, T.D. and M. Newton. 1985. Growth of Douglas-fir following control of snowbrush and herbaceous vegetation in Oregon. Down To Earth 41(1): 21-25.

Pinto, F., D. Pearce and D. Nesbitt. 2003. Silviculture Treatment Assessment and Reporting System (STARS): Background and field manual. Ont. Min. Nat. Resour., Nat. Resour. Inf. Centre. Peterborough, ON. 20 p.

Pitt, D.G., C.S. Krishka, F.W. Bell and A. Lehela. 1999. Five year performance of three conifer stock types on fine sandy loam soils treated with hexazinone. North. J. Appl. For. 16: 72-81.

Pitt, D.G., A.E. Morneault, P. Bunce and F.W. Bell. 2000. Five years of vegetation succession following vegetation management treatments in a jack pine ecosystem. North. J. Appl. For. 17: 100-109.

Pitt, D.G., R.G. Wagner and W.D. Towill. 2004. Ten years of vegetation succession following ground-applied release treatments in young black spruce plantations. North. J. Appl. For. 21: 123-134. 
Rose, R. and J. Coate. 2000. Reforestation rules in Oregon - lessons learned from strict enforcement. J. For. May: 24-28.

Rose, R., L.S. Rosner and J.S. Ketchum. 2006. Twelfth-year response of Douglas-fir to area of weed control and herbaceous versus woody weed control treatments. Can. J. For. Res. 36: 2464-2473. SAS Institute. 2004. SAS OnlineDoc ${ }^{\circledR}$ 9.1.3. SAS Institute Inc., Cary, NC.

[SEFS] Saskatchewan Environment Forest Service. 2004. Regeneration assessment. Sask. Environ. For. Serv., Prince Albert, SK. 42 p. Sims, R.A., W.D. Towill, K.A. Baldwin and G.M. Wickware. 1989. Field guide to the forest ecosystem classification for Northwestern Ontario. Ont. Min. Nat. Resour., Northwest Sci. Technol., Thunder Bay, ON. 191 p.

South, D.B. and W.L. Mason. 1993. Influence of differences in planting stock size on early height growth of Sitka spruce. Forestry 66: 83-96.

South, D.B. and R.J. Mitchell. 1999. Determining the "optimum" slash pine seedling size for use with four levels of vegetation management on a flatwoods site in Georgia, U.S.A. Can. J. For. Res. 29: 1039-1046.

Wagner, R.G. 2000. Competition and critical-period thresholds for vegetation management decisions in young conifer stands. For. Chron. 76(6): 961-967.

Wagner, R.G., L.J. Buse, R.A. Lautenschlager, F.W. Bell, C. Hollstedt, S. Strobl, A. Morneault, W. Lewis and M.T. Ter-Mikaelian. 1994. Vegetation management alternatives program: 1994-1995 Annual Report. Ont. Min. Nat. Resour., Ont. For. Res. Inst., Sault Ste Marie, ON. 84 p.
Wagner, R.G., T.L. Noland and G.H. Mohammed. 1996. Timing and duration of herbaceous vegetation control around four northern coniferous species. N.Z. J. For. 26 (1/2): 39-52.

Wagner, R.G. and S.R. Radosevich. 1998. Neighborhood approach for quantifying interspecific competition in coastal Oregon forests. Ecol. Applic. 8(3): 779-794.

White, R.G., C.L. Bowling, W.J. Parton and W.D. Towill. 2005. Well-spaced free-growing regeneration assessment procedure for Ontario. Ont. Min. Nat. Resour., Northwest Sci. Info., Thunder Bay, ON. NWSI Tech. Man. TM-007. 38 p.

White, R.G., D.E.B. Reid and N.J. Buda. 2009. A decision framework for developing regeneration standards. Ont. Min. Nat. Resour., Northwest Sci. Info., Thunder Bay, ON. NWSI Tech. Man. TM-009. 15 p. + append.

Zedaker, S.M. and J.H. Miller. 1991. Measurements of target and crop species. In J.H. Miller and G.R. Glover (eds.).Standard Methods for Forest Herbicide Research, pp. 22-40. Southern Weed Science Society of America, Champaign, IL.

Zutter, B.R. and J.H. Miller. 1998. Eleventh-year response of loblolly pine and competing vegetation to woody and herbaceous plant control on a Georgia flatwoods site. South. J. Appl. For. 22: 85-95.

Zutter, B.R., J.H. Miller, S.M. Zedaker, M.B. Edwards and R.A. Newbold. 1995. Response of loblolly pine plantations to woody and herbaceous control - eighth-year results of the region wide study the COM Project. In M.B. Edwards (comp.). Proc. 8th Biennial Southern Silvicultural Res. Conf., 1-3 Nov. 1994, Auburn, AL. pp. 75-80. USDA For. Serv., Gen. Tech. Rep. SRS-1. 